\title{
From Fan Culture/Community to the Fan World: Possible Pathways and Ways of Having Done Fandom
}

\section{Matt Hills ${ }^{1}$}

Recibido: 2017-07-16

Enviado a pares: 2017-07-24
Aprobado por pares: 2017-07-27

Aceptado: 2017-08-15

DOI: 10.5294/pacla.2017.20.4.2

Para citar este artículo / to reference this article / para citar este artigo

Hills, M. (2017). From Fan Culture/Community to the Fan World: Possible Pathways and Ways of Having Done Fandom. Palabra Clave 20(4), 856-883. DOI: 10.5294/pacla.2017.20.4.2

\section{Abstract}

In this article I revisit concepts of fan culture and community, which have been central to fan studies. Critiques of subcultural theory, along with fandom's fragmentation into "traditional" fans and "brand fans," have suggested that media fandom cannot be viewed as a coherent culture or community. Consequently, I consider how a concept of fan world addresses some of these emergent critiques of fan culture/community, setting out what a world theory can offer current debates surrounding fandom. I draw particularly on Howard Becker's approach to art worlds (Becker, 2008) and Steven Connor's overview of world concepts (Connor, 2010). This allows me to elaborate on a model of the fan world, moving away from a position where world theories have usually been adopted in relation to franchises' world building to think about the platforms and pathways through which fandom is performed today. Ways of "having done fandom" are chosen, more or less reflexively, by fans from an array of communal and individualized possibilities. And "paths not taken" become counterfactual as fans follow certain bran-

1 orcid.org/0000-0002-8778-6530. University of Huddersfield, England. M.J.Hills@hud.ac.uk 
ches of fan activity but not others, developing specific forms of fan specialization and positioning rather than others (Giddens, 1991). The fan world represents this open necessity of having to choose particular fan pathways within the contemporary "participatory condition," itself being comprised of all possible versions and branches of fan identity.

\section{Keywords}

Fan culture; fan community; subculture; world; Howard Becker (Source: Unesco Thesaurus). 


\section{De la cultura/comunidad del fan al mundo del fan: posibles vías y maneras de hacer Fandom}

\section{Resumen}

En este artículo retomo los conceptos de la cultura y la comunidad del fan, que han sido centrales para los estudios de los fans. Las críticas de la teoría subcultural, junto con la fragmentación del fandom en fans "tradicionales" y "de marca", han sugerido que el fandom de los medios no puede ser visto como una cultura o comunidad coherente. En consecuencia, considero cómo un concepto del mundo de los fans aborda algunas de estas críticas emergentes de la cultura/comunidad de los fans, exponiendo lo que una teoría mundial puede ofrecer a los debates actuales sobre el fandom. Me interesa particularmente el enfoque de Howard Becker sobre los mundos del arte (Becker, 2008) y la visión general de Steven Connor sobre los conceptos de mundo (Connor, 2010). Esto me permite elaborar un modelo del mundo de los fans, alejándome de una posición en la que las teorías del mundo se han adoptado generalmente en relación con la construcción del mundo de las franquicias para pensar en las plataformas y vías a través de las cuales se practica el fandom actualmente. Las formas de "hacer fandom" son elegidas, más o menos reflexivamente, por los fans a partir de una serie de posibilidades comunes e individualizadas. Y las "vías que no se toman" se vuelven contrafácticas ya que los fans siguen ciertas ramas de la actividad de los fans en vez de otras, desarrollando formas específicas de especialización y posicionamiento de los fans en lugar de otras (Giddens, 1991). El mundo de los fans representa esta necesidad abierta de tener que elegir vías específicas del fan dentro de la "condición participativa” contemporánea, que se compone de todas las posibles versiones y ramas de la identidad del fan.

\section{Palabras clave}

Cultura del fan; comunidad del fan; subcultura; mundo; Howard Becker (Fuente: Tesauro de la Unesco). 


\section{Da cultura/comunidade do fã ao mundo do fã: possíveis vias e maneiras de fazer fandom}

\section{Resumo}

Neste artigo volto aos conceitos da cultura e da comunidade do fã, que têm sido foco para os estudos dos fãs. As críticas da teoria sub-cultural, junto com a fragmentação do fandom em fãs "tradicionais" e "de marca", tem sugerido que o fandom da mídia não pode ser visto como uma cultura ou comunidade coerente. Em consequência, considero como um conceito do mundo dos fãs aborda algumas destas críticas emergentes da cultura/comunidade dos fãs, expondo o que uma teoria mundial pode oferecer aos debates atuais sobre ofandom. Interessa-me particularmente o foco de Howard Becker sobre os mundos da arte (Becker, 2008) e a visão geral de Steven Connor sobre os conceitos de mundo (Connor, 2010). Isto me permite elaborar um modelo do mundo dos fãs, afastando-me de uma posição na qual as teorias do mundo foram adoptadas geralmente com relação à construção do mundo das franquias para pensar nas plataformas e vias através das quais se pratica o fandom atualmente. As formas de "fazer fandom" são eleitas, mais ou menos reflexivamente, pelos fãs de uma série de possibilidades comuns e individualizadas. E as "vias que não se tomam" tornam-se contra fáticas já que os fãs seguem certos ramos de atividade, e não outros, desenvolvendo formas específicas de especialização e posicionamento dos fãs em vez de outras (Giddens, 1991). O mundo dos fãs representa esta necessidade aberta de ter que escolher vias específicas do fã dentro da "condição participativa” contemporânea, que se compõe de todas as possíveis versões e ramos da identidade do fã.

\section{Palavras-chave}

Cultura do fã; comunidade do fã; subcultura; mundo; Howard Becker (Fonte: Tesauro da Unesco). 
In this article I want to revisit and problematize the notions of fan culture and community, which have been central —usually in unquestioned and common-sense ways - to the emergence and consolidation of fan studies across at least several decades. Although the concept of fan community has sometimes been questioned (Van de Goor, 2015; Hill, 2016; Hitchcock Morimoto \& Chin, 2017), an overarching notion of fan culture has more often remained solidly in place, resonating with the broader acceptance in media/cultural studies that a vast array of objects of study can be framed in this way, from material culture to commercial cultures (Woodward, 2007; Jackson et al., 2000) to popular culture and beyond. I have had a role in all of this, publishing the book Fan Cultures in 2002, but the concept has continued to possess currency in the field, as witnessed by the similarly titled Fan Culture: Theory/Practice some ten years later (Larsen \& Zubernis, 2012) and by the more recent Fans and Fan Cultures (Linden \& Linden, 2017). The first journal of fandom (2008-present) also retains an emphasis on fan cultures that is flagged up in its title: Transformative Works and Cultures.

However, fan culture has, like community, begun to be called into question. Writing in The Mediated Construction of Reality, for example, Nick Couldry and Andreas Hepp (2017) argue that "instead of understanding each and every fan culture necessarily as a single community, we might do better to understand it as a complex figuration of figurations that links up different local groups in a range of interdependent [and sometimes independent- $\mathrm{MH}$ ] activities" (p. 171). The suggestion is that we may need to approach contemporary fandom not as a singular or coherent "culture" (if we ever really could), but rather as a network of networks, or a loose affiliation of sub-subcultures, all specializing in different modes of fan activity. I will explore this in my opening section below, considering whether a concept of fan world might work to address some of the emergent critiques of fan culture/community and analyses of fragmentation. I will then move on to set out in more detail what a world concept can offer contemporary debates surrounding media fandom, drawing on Howard Becker's "art worlds" and Nelson Goodman's view of "worldmaking" (Becker, 2008; Goodman, 1978). This will enable me to elaborate on a model of the fan world here, noting that world theories have usually been adopted in relation to media 
franchises' hyperdiegetic storyworlds and transmedia storytelling (Jenkins, 2006, p. 114). That is, fans have been figured as consumers immersed in "imaginary worlds," investing their "affective labor" in others' world building (Hassler-Forest, 2016, pp. 10-11), rather than as inhabitants of a fan world in their own right. Thus, one of my aims in this essay is to repurpose the world concept, shifting it from its current place in world building discussions - which view fandom as a matter of retconning/fixing/contesting commercial storyworlds - and towards a sense of how passionate audiences can come to occupy specific positions in the fan world. First, though, why might we need to move away from settled notions of fan culture?

\section{Fan Culture? From Singular Community to Critiques of Subcultural Differentiation}

Although Henry Jenkins didn't use the term in Textual Poachers (1992), the media fans he studied were all fans of what has become known as "cult TV": Star Trek, Doctor Who, Blake's 7, The Prisoner, Alien Nation, Beauty and the Beast, and so on. Indeed, by focusing ethnographically on a sense of fan community, Jenkins (1992) was explicitly building on earlier subcultural theory, as well as feminist critiques of this. By initiating this subculturally-indebted approach to media fandom, Jenkins (1992) defined it as a

discursive logic that knits together interests across textual and generic boundaries. While some fans remain exclusively committed to a single show or star, many others use individual series as a point of entry into a broader fan community, linking to an inter-textual network composed of many programs, films, books, comics (p. 40).

It is this "broader fan community," not focused around lone TV shows, that has underpinned the concept of fan culture, and which a number of scholars-Jenkins included-have gone on to view as crucial to theorizing and understanding fandom. For instance, Alexis Lothian (2013) has gone so far as to explicitly label the phenomenon subcultural fandom, whilst Karen Hellekson $(2009,2015)$ has similarly emphasized the gift economy shared by media fans, and its on-going detachment from "imposed" commerciality. 
However, the notion of a subcultural fandom, or a discernible fan culture at least somewhat at odds with its neoliberal media context, has become increasingly problematic in the era of social media and Web 2.0. Kristina Busse and Jonathan Gray (2014) distinguish between "traditional fan communities and [the] new industry-driven fans... [of] contemporary convergence culture" (p. 431), for instance, and Henrik and Sara Linden (2017) have also adopted a bifurcated approach to fandom, addressing "the similarities and differences between 'traditional' fans and 'brand fans'... with an emphasis on (post)subcultural aspects and fans as consumers in a capitalist consumer society" (p. 37). Rather than representing fandom tout court, fan community/culture becomes just one version of media fandom here:

\begin{abstract}
While fan studies in its early stages _ ...the "Fandom is Beautiful" era-focused largely on fans and fan cultures as communities who worked together to help democratize the meaning-making in popular culture discourse, in recent years more emphasis has been placed on fandom as empowering for individual members of fan networks. What aligns these two modes of approaching fan studies is the focus on fandom as participatory culture. (Linden \& Linden, 2017, p. 37)
\end{abstract}

In fact, this doubling of fandom is present in Linden and Linden's very book title, which, by nominating Fans and fan cultures, starts to cleave fandom into those who are part of a culture/community (the "traditional" fan) and those who, as "brand fans," can operate outside any sense of fan community or experienced fan culture.

This challenge to subcultural fandom, and hence to a notion of differentiating fan culture, has also been emblematically debated between the editors of the volume Fandom (now in a second edition; see Sandvoss et al., 2017) and Francesca Coppa, writing in the Journal of Fandom Studies. Coppa takes issue with the characterization of "first wave" fan studies' analysis as involving a "Fandom is Beautiful" approach (Sandvoss et al., 2017), and the possibility that fan studies should move beyond studying fan community:

arguably this broadening of subject represents a change of subject. It seems unfair to say that early fandom scholars overlooked the broad spectrum of regular fans to focus on... the creators and participators 
for whom fandom was a way of life ... when that was precisely their defined object of study. (Coppa, 2014, p. 74)

It is fan community-i.e., fan culture-that largely forms the object of dispute here, with Coppa (2014) suggesting that "the fandom of Fandom no longer describes a community of people” (p. 74). Responding to this critique, the editors of Fandom argue that fan cultures should continue to be studied alongside more individualized and personalized fan affects: "Studies of fans need not all be discussing the same types of fans, practices, or engagements to have a symphonic quality when considered in total" (Sandvoss et al., 2017, p. 10). However, they also argue that returning to a "Fandom is Beautiful" or "first wave" stance would mean "misreading particular fan groups as singularly representative of all fan practices and motivations" (Sandvoss et al., 2017, p. 10). The danger for scholarship here lies, according to Fandom's editors, in

\begin{abstract}
reinforcing a binary distinction between fans and "normal audiences" that much of the first wave of fan studies embraced, reaching as far back as [John] Fiske's work... The object of study is defined through its adherence to a preconceived conceptual position leading to a circular logic: fans are found to be highly networked and participatory, because to be considered fans they need to be highly networked and participatory (Sandvoss et al., 2017, pp. 9-10).
\end{abstract}

In other words, asserting that "Fuck yeah, fandom is beautiful" (Coppa, 2014, p. 74) allegedly means positioning fan community/culture as "authentic" fandom versus a version of non-communal fandom viewed as secondary, and as lacking in historical roots and knowledge (Busse \& Gray, 2014, p. 431). Without the "group social participation" of fan community, and the "critical sensibility that comes from engaging culture from the inside, as someone with a defined role in the cultural ecosystem" (Coppa, 2014, p. 78), Francesca Coppa (2014) counters that fandom is "in danger of being owned: our work, our communications, our relationships to and with each other. Fandom is more than its economic/revenue potential” (p. 80).

The binary that underpins Coppa's defense of fandom community is thus not as clearly one of fan culture versus "normal audiences," as Sand- 
voss et al. (2017) imply. Instead, the binary is one of fan community and culture ("[b]eing in fandom") versus thoroughgoing fan industrial co-optation. Nonetheless, there is a sense of fan culture as differentiated that underlies the work of Coppa (2014), Hellekson (2015), and Lothian (2013), where being "in fandom can change a person, who in taking on the identity of 'fan' may also come to take on additional identities - that of a writer, blogger, film-maker, organizer, activist, etc. - that impact her sense of self and the way she engages the world" (Coppa, 2014, p. 78).

If subcultural fandom and the concept of fan culture as differentiated and differentiating - i.e. fan subculture vs. mainstream culture- have been called into question through a doubling of kinds of fandom (communal or individualized), then subcultural theory itself has undergone a similar splitting. For example, subcultural capital (Thornton, 1995), i.e., the specialist knowledge that defines a "true" subculturalist, has been divided into "mundane" and "transgressive" variants by Keith Kahn-Harris (2007). A tension between "the joys of collective activity" and "radical individualism" remains present here (Kahn-Harris, 2007, p. 122 and p. 127), with mundane subcultural capital being "oriented towards the ... collective... It is a form of capital accrued through a sustained investment in the myriad practices through which the scene is reproduced" (Kahn-Harris, 2007, p. 122), whilst transgressive subcultural capital "can be claimed through a critique of the scene itself” (Kahn-Harris, 2007, p. 127). The "mundane” form means fitting into a subculture (or fan culture), whereas its "transgressive" version means "displaying uniqueness" by criticizing the culture from within (Kahn-Harris, 2007, p. 127).

Erik Hannerz (2015) has likewise set out "a model of two distinct subcultural patterns of meaning based on how the mainstream is defined and positioned as well as how the subcultural sacred is mobilized and authenticated" (p. 35). Drawing on extensive empirical work (as does Kahn-Harris), Hannerz (2015) identifies these patterns as "convex" and "concave," where "a convex pattern bends outwards, defining the mainstream as external ... and a concave pattern bends inwards, positioning the mainstream as internal" to the subculture (p.35). Although this makes "the separation 
from the mainstream a subcultural construction" (Hannerz, 2015, p. 36), as we might expect, it also renders such a separation multiple. Subculturalists can "move in and out of these patterns, over time and between spaces" (Hannerz, 2015, p. 36) as they define "authentic" participation (or indeed fandom) against an externalized mainstream or a sold-out, compliant, derivative and mainstream version of their own subculture. In fact, Hannerz's concave subcultural difference sounds uncannily like Francesca Coppa's dismissal of San Diego Comic-Con as inauthentic: "an industry convention disguised as a fan convention" (Coppa, 2014, p. 80). And at the same time, Sandvoss et al's (2017) call for a version of fan studies that broadens out the "us" of fandom can sound a lot like Kahn-Harris's transgressive subcultural capital, aiming to critique fan studies' focus on versions of fandom that have been powerfully marked by whiteness, for example (Fathallah, 2017).

Fan studies has, perhaps, been a little slow to integrate developments in subcultural theory into its understandings of media fandom. By doing so, and hence by thinking about "fan cultural capital" (Hills, 2002, p. 57) as mundane/transgressive, or as occurring within convex/concave patterns of anti-mainstream meaning, we might successfully complicate dominant notions of fan culture. However, such developments merely substitute binary fan communities for a singular notion of fan difference, resituating "authentic" fan difference as a matter of division within the fan community. Fan culture may already have become far more plural than this. As Louisa Stein (2015) observes in her book Millennial Fandom:

\begin{abstract}
Just as professionalism as an aesthetic may move through commercial and fan work, so too may the ethics of professionalism extend into fan communities and to the creative works of fans. These ethics can come directly in[to] conflict with even such a seemingly core fannish value as the... right to transform. Rather than being uniformly held millennial fan values, affective collectivity and fan transformation exist in tension with discourses of individual professionalism. (p. 160)
\end{abstract}

Such diversity can thus incorporate what Oliver Carter (forthcoming) has termed "fantrepreneurship" or the "fantrepreneur"- someone who makes money from the small-scale (and possibly grey market) com- 
mercial exploitation of their fan knowledge. Such activity, e.g., fans setting up small businesses on Etsy to supply materials such as colored yarn to multiple fandoms (Cherry, 2016, pp. 166-167), can occur without fandom necessarily positioning this as a "concave" subcultural mainstream. Whether designing T-shirts or dyeing yarn, "petty producers" have often been accepted within fandom (Abercrombie \& Longhurst, 1998, p. 150). Consequently, splitting the phenomenon into "brand fans" operating within neoliberal entrepreneurialism and "traditional" anti-commercial fans may be reductive (Hills, 2017a). The subcultural differentiation of media fandom starts to seem problematic or even unsustainable here, as Adrian Athique (2016) has argued:

\begin{abstract}
For audience researchers, probably the most discussed "point of convergence" in the Internet era is that between fan subcultures and mainstream audiences. It appears that the contemporary "mainstream" is not, after all, a dispassionate and generalized alternative to cult behaviors, but actually a vast field of overlapping fan cultures. Consequently, ...the enabling anthropological concept of subcultures as singular communities is dead in the water (p. 153).
\end{abstract}

Instead, we could argue that subcultural fandom continues to imagine itself — and be imagined by at least some scholars — as a differentiated domain of fan practice on the basis of an idealization: "this idea of a community is idealistic and nostalgic and exists in contradiction with the experiences of community members so that it portrays an ideal rather than a lived reality" (Hill, 2016, p. 40). Rosemary Lucy Hill terms this an "imaginary community," arguing that fan studies needs to not only focus on the "visible fans" of "subculture" but also "those whose fandom is usually hidden” (Hill, 2016, p. 37; see also Sandvoss et al., 2017, pp. 10-11) rather than performed in public or online.

Another critique of fan subculture as a "singular" community comes from Thomas Lindlof's (2015) attack on the concept of interpretive community. This notion has also been present in fan studies from at least Henry Jenkins' (1992) Textual Poachers onwards (in fact, it is applied in Cassandra Amesley's 1989 journal article on "How to watch Star Trek"). Lindlof (2015) argues that interpretive community as a "concept is... inadequate 
because of its traditional focus on an isolated text that stays the same for all audience members. This focus is dramatically at odds with ... the mobility of reading/writing strategies within and across platforms" (p. 30). Instead, given the many platform-specific or even forum-specific audience groups that can form in relation to media texts, Lindlof (2015) ponders whether there may now be "a cultural long tail: a vision of incredibly numerous interpretive communities receding into the distance" (p. 33) as they each share their passions online with a particular group that cannot be aligned with an overarching fan community or culture. As he asks, "[w] here is the community located if it isn't attached to a single text...?” (Lindlof, 2015, p.33). On this account, fans reading their fan object through an engagement with fanfic archives (De Kosnik, 2016), e.g. fic tagged at Archive of Our Own, wouldn't necessarily constitute "subcultural fandom," (contra Lothian, 2013, p. 545), but would simply act as one version of fan interpretive community among many non-coalescing and separate others. At this point, it becomes questionable as to how useful it remains to think of fandom in terms of fan community and culture-we are quite some distance from Jenkins' (1992) "broader fan community" (p. 40).

An alternative term has appeared within these debates over fan culture/community, however, and it is one that may offer a productive way into theorizing fandom's multiplicity, its specializations of practice within differing networks, and its increasing permeability to commercialism or neoliberalism within a diverse array of activities and interpretations. With fandom's subcultural differentiation potentially giving way to internal division or communal/individualized versions of "subcultural capital", and with varied incarnations of fandom occurring outside subcultural domains, the notion of fan culture has become ever more stretched. Or, rather, it has become ever more applicable only to a subset of fan discourses, experiences and practices: "if 'everyone' is a fan, then we must move beyond subcultures” (Linden \& Linden, 2017, p. 43). Here is how Henrik and Sara Linden justify their critique of fan subculture:

although participatory culture is a positive force it may be that the value of fandom as transformative agency has been overrated. 
The whole world is like a computer game with pre-decided options to choose from. They may seem vast, but they are limited. (Linden \& Linden, 2017, p. 50)

And here, in turn, is how Francesca Coppa, opposing the kind of position that Linden and Linden set out, argues in favor of maintaining a focus on subcultural fandom/fan culture:

\begin{abstract}
a fan studies that takes as its subject the self-identified fans who participate in some kind of fan culture-as writers, artists, vidders, film-makers, con organizers, community moderators, coders, archivists, game designers, bloggers, wikifiers, cosplayers, beta readers, gif-makers, episode reviewers, fanwork critics, fandom activists, and more-is a fan studies that is focused on a rapidly growing network that can have, and is having, huge real world effects. (Coppa, 2014, p. 77)
\end{abstract}

Each side of this debate anchors its (moral) claim over what fandom "is" with some concept of the world - "the whole world" limits how differentiated or anti-commercial fandom can be for Linden and Linden, whereas it is the "real world" that demonstrates the material outcomes of subcultural fan creativity (and transformative works) for Coppa. The world, though, is always discursively situated outside fandom in these discussions: it is the limiting frame, or the space that fan productivity acts upon. This is an image that Lori Hitchcock Morimoto and Bertha Chin (2017) perfectly encapsulate when they observe that "fandom is always performed against a backdrop of real-world events, constraints, and subjectivities" (p. 181). But what if we didn't use some undefined and suspiciously untheorized concept of the "whole" or the "real" world to anchor ontological claims surrounding contemporary fandom? What if rather than treating the world as a common-sensical "backdrop" to fan culture, we thought about the fan world in ways that might respond to critiques of subcultural fandom and fan difference? This is the argument that I want to develop here. To do so I need to take a detour through theories of worldness before re-articulating fan studies' approaches with a more refined view of the fan world. 


\section{Fan World? From World Building to Conditions of Open Necessity}

World building has been the leading way that world-related concepts have entered fan studies over the past decade or so, following on from Henry Jenkins' (2006) argument in Convergence Culture that media "storytelling has become the art of world building, as artists create compelling environments that cannot be fully explored or exhausted within a single work or even a single medium" (p. 114). Edited collections (Boni, 2017) and soleauthored monographs (Hassler-Forest, 2016) have explored fan practices in relation to transmedia storytelling (Freeman, 2017) and world building where the fictional "world is bigger than the film, bigger even than the franchise-since fan speculation and elaborations also expand the world in a variety of directions" (Jenkins, 2006, p. 114). But this tendency leaves the world concept in play only for "imaginary worlds" and how they might intersect with and incite fan activities (Saler, 2012; Wolf, 2012). Possible worlds semantics has also underpinned a related and influential approach within narratology (see Thon, 2016, p. 39, for a list of key scholars).

Whether "imaginary" or "possible", these are contained and created worlds which can be consumed for pleasure as well as learnt about and mapped by fans. Immersion is often assumed to be a crucial fan pleasure of such worlds (Hills, 2017b), and Marie-Laure Ryan (2017), in a perceptive discussion of "Why worlds now?," suggests that the "phenomenological conception of world [underlying media-technological imaginary worlds] rests on two properties:... worlds are immersive... and ... they are interactive" (p. 9). Ryan (2017) argues that although "[c] osmology and philosophy may be part of the cultural background against which the notion of world rose to prominence, ... the force that truly explains its current popularity... is the media that bring imaginary worlds into our lives" (p. 10), and furthermore that fandom can render any mediated immersive world interactive through the generation of fanfic and fan art, etc.

However, rather than relegating cosmology and philosophy to the cultural background in favor of foregrounding transmedia world building and imaginary worlds as work on fandom has tended to do, I'm interested 
in these definitions and debates. Ryan (2017) notes that world concepts have become ever more expansive, ranging cosmologically from the "sense of world as a celestial object, functioning as container for a variety of life forms... [to] an infinity of worlds because space is infinite ... and has room for all possible arrangements of matter" (p. 4). Similarly, possible worlds theory has set out to explore a "multiverse" (Ryan, 2017, p. 5) of counterfactuals. Both cosmologically and philosophically, then, world has come to stand in for "everything that exists" (Ryan, 2017, p. 9), in marked contradistinction to the "medial/technological perspective on worlds" (Ryan, 2017, p. 9) that has typically been favored in work on fandom.

Steven Connor (2010) sets out succinctly what is at stake in these two different approaches when he furnishes a "ludicrously brief history of the concept of 'the world', noting that "the phrase 'the whole world' does not seem to appear frequently in English until the sixteenth century. I can find no instance of it before its appearance in William Tyndale's $\mathrm{Pa}$ rable of The Wicked Mammon of 1528” (pp.29-30). For Connor (2010), drawing on Nelson Goodman's (1978) theory of "worldmaking," which has also been used to theorize fictional/imaginary worlds (Nünning \& Nünning, 2010),

The most important difference between what Goodman seems to mean by "a world" and "the world" is the following: A world is strongly determined but weakly determining. By contrast, the world is strongly determining but weakly determined. ... It is not just the largeness and variousness of the world that makes it unspecifiable. It is because the world is an open necessity. There is no necessity for the world to be constituted in any way in particular, but it is absolutely necessary that it will come to be constituted in some particular way or ways that are always more finite than the current possibilities. (Connor, 2010, p. 42)

In marked contrast, Connor (2010) argues that a world, which can be a symbolic or fictional world, or indeed "the same kind of thing that we refer to when we use words like cultures, civilizations, mythologies, frames of reference, discursive regimes, idioms, games, rituals, clubs, cliques, clans and gangs" (p. 42) is generated and sustained by "frameworks [that] can be so strongly and persuasively specified, ... their grammar... so readily legible, 
... [that this] makes it impossible for them to contain us. We can step outside them precisely because we can see around them" (Connor, 2010, p. 42).

On this basis, it may seem that Steven Connor would view fan culture as a world of specifiable discourses and grammars that fans can oppose, opt out of, or "step outside" of if they are felt to be too constricting. But this would merely replay a notion of fan-cultural or subcultural differentiation under a different guise, reading fandom as a "gang" that one can move in and out of without any cultural consequence. Yet fans' lived experience occurs not merely in "a world" but necessarily in "the world" (again, I want to avoid a splitting which reduces the world to a backdrop or shadowy external figure that fans engage with). And as a result,

being in the world means only being able to have lived in one world. Of course one is able to choose, maybe constrained to choose, among many worlds. But one will have chosen only one, or only one conglomerate. The world is an issue of the future perfect... a retrospective construal. (Connor, 2010, p. 42)

Indeed, Anthony Giddens (1991) locates this as a sociological fact when he theorizes late modernity and people's self-narratives: "Because of its reflexively mobilized ... dynamism, modern social activity has an essentially counterfactual character" (p. 28). That is, possible worlds cease to be an arcane matter of modal logic and inform social actuality:

In a post-traditional social universe, an indefinite range of potential courses of action (with their attendant risks) is at any given moment open to individuals and collectivities. Choosing among such alternatives is always an "as if" matter, a question of selecting between "possible worlds." Living in circumstances of modernity is best understood as a matter of the routine contemplation of counterfactuals (Giddens, 1991, pp. 28-29).

On this account, fandom is not merely a world among a multiplicity of cultural or subcultural worlds, as Nelson Goodman's (1978) concept of worldmaking would perhaps imply. Rather, the fan world emerges through a necessary choice between alternatives: to become part of a self-identified fandom (or not); to do so through specific social media platforms or 
as part of specific fan groups (or not); to do so by attending fan conventions (or not); to devote specific time and economic resources to "being a fan," and so on.

Rather than forming a closed system of highly legible rules or grammars (a fan-cultural perspective), I am arguing that fandom has increasingly displayed a "largeness and variousness ... that makes it unspecifiable" in Connor's (2010, p. 42) sense: i.e., lived fandom will "come to be constituted in some particular way or ways that are always more finite than the current possibilities" (Connor, 2010, p. 42) comprised by what it could mean to be a fan. Does one write fanfic? Collect kinds of merchandise or screenused props/costumes? Blog about a beloved fan object? Craft material artefacts resembling those that appear in popular media?

It may be objected that the fan world has no "open necessity" (Connor, 2010, p. 42) insofar as one does not need to become a fan of anything. But this objection neglects to consider the extent to which, in the current conjuncture, participation has become a "general condition in which many of us live... It has become a contextual feature of everyday life in the liberal, capitalist, and technological societies of the contemporary West" (Barney et al., 2016, p. vii). Such a "participatory condition ... both environmental (a state of affairs) and normative” (Barney et al., 2016, p. vii) is eminently distinguishable from the participatory culture which Henry Jenkins (1992) identified with media fandom in Textual Poachers. Rather than the issue being whether one wants or chooses to become a subcultural fan, the question now becomes: if "participatory culture is the norm, how does one who does not like to share his or her... convictions and attitude take part in such a process?" (Janissary Collective, 2013, p. 261). And although participatory culture is not coterminous with fandom, I would argue that the emerging distinction that multiple scholars have marked out between "traditional fans" and "brand fans" or "industry-driven fans" captures a sense of this "participatory condition" where even those who do not self-identify as part of a fan community can nonetheless be perfectly well analyzed and theorized, on the basis of their digital practices, as a kind of fan, i.e., as following one possible pathway within the wider fan world. 
As well as constituting an "open necessity" within the current sociohistorical context (and not only in the West), what I am beginning to term the "fan world" also displays another kind of openness. This further condition is grounded in Howard S. Becker's work on art worlds, where Becker (2008) concludes that his

analysis centers on some kind of collective activity, something that people are doing together. Whoever contributes in any way to that activity and its results is part of that world. The line drawn to separate the world from whatever is not part of it is an analytic convenience, not something that exists... So the world is not a closed unit. (p. 376)

By emphasizing this type of openness, Becker contrasts his use of a world metaphor to that of Pierre Bourdieu's competing "field" image (Bourdieu, 1993), suggesting that Bourdieu's stance reinforces a problematic view of fields as overly bounded, excessively competitive rather than also being co-operative, and exaggeratedly oriented around a scenario in which "the power to define what is important or acceptable" rests "stably with one set of actors" (Becker, 2008, p. 379). In contrast to this, Becker (2008) argues that "the idea of 'world' makes sense" (p. 379) if we adopt a more inclusive and decentered approach:

everyone who participates in making a work participates in making it. The advantage of that tautology is that it shows us how to incorporate into our conception of art-making the people who are conventionally left out of such an analysis: the technicians, the money people, all the people I have called "support personnel" (Becker, 2008, p. 384).

And even more explicitly, again contra Bourdieu's theorizations, Becker (2008) states that "[a]rt worlds do not have boundaries around them, so that we can say that these people belong to a particular art world while those people do not" (p. 35). This also runs strongly counter to a view of subcultural fandom, and thus of differentiated fan culture. Taking Becker's art world as another model for the fan world would therefore mean recognizing how fandom is supported and enabled by a range of professional cultural intermediaries (those working in $\mathrm{PR}$ and paratextual industries, for instance) as well as people seemingly "outside" a fan community also deserving and requiring fan studies' analysis. As Becker (2008) observes, "it is 
not clear what to include in an analysis of art worlds and what to leave out," and limiting study to "what a society currently defines as art [or in this case, fandom - MH] leaves out too much that is interesting," as well as allowing "the processes of definition by members of the society, which ought properly to be the subject of our study, to set its terms" (p. 37). In other words, as long as what counts as art is disputed, given that "[a]rt worlds typically devote considerable attention to trying to decide what is and isn't art, what is and isn't their kind of art, and who is and isn't an artist" (Becker, 2008, p. 36), then such authenticity claims should be set to one side by scholars.

I would argue that, analogously, the same must be true for those working in fan studies: rather than allowing members of fandom to set the terms of fandom's study, we should remain open to marginal cases as well as those where people are not interested in claiming the name or definition of fandom (Becker, 2008, p. 37). Just as art worlds may expend great energy on trying to pin down "their kind of art", so the fan world can also extensively police what should be counted as "authentic" fandom (Pope, 2017, p. 88 and p. 90) as well as "their kind of fan" for a specific fan grouping, network or specialization in practice. If we (re)construct binaries in scholarship which valorize traditional fans as somehow more authentic than industry-driven or brand fans then we are positioning one possible pathway within the fan world as "true" fandom, and hence prioritizing just one particular way of doing fandom that is "always more finite than the current possibilities" (Connor, 2010, p. 42). Rather than selecting out one possible world of fandom (which may also happen to be the branch of fandom occupied by that particular acafan), analyzing the fan world means considering how self-identified fans (and those who do not use the label) can be located among the series of possibilities, platforms and practices that go to make up fandom's relational array. Such varied incarnations of (disputed or unauthenticated) fandom cannot academically take on a "symphonic quality," however, as Sandvoss et al. (2017, p. 10) imply, for the very reason that these different pathways and possibilities will necessarily resolve the specific fan's practices into having "lived in one [possible] world" of fandom where "one will have chosen only one" way of being a fan (Connor, 2010, p. 42). Hence, different versions will be subjected to the disapproval, discursive policing, 
othering, or more-or-less active neglect (and even ignorance) of those occupying alternative branches of the fan world. The possibilities for ways of having done fandom do not cohere into a single community, whether interpretive or not. Neither can they resolve into any harmonious or final set at the level of academic cataloguing, and nor are they part of an overarching culture, instead remaining fractious, fractionated and in some cases merely disconnected from one another. For example, skilled and knowledgeable fanfic writers may, at the same time, have little to no knowledge of high-end fan collectors' practices, and vice versa. Rather than participating in a mutual othering or devaluation of one another's fan practices, these ways of having done fandom may simply remain counterfactual within each type of fan specialization.

Although this world concept has largely been neglected in fan studies, it is in fact briefly present in Jenkins' (1992) seminal Textual Poachers. Despite drawing his major theoretical inspiration from Michel de Certeau, Jenkins (1992) also touches on the relevance of Becker's art world conceptualization, making this something of a path not taken for fan studies, it might be said. However, by integrating Becker's work into his overall view of a "broader fan community," Jenkins (1992) tends to read art worlds as if they can be closed units rather than opening on to a range of supporting figures and hence having an ultimate indeterminacy. As Becker (2008) himself puts it: "I am not concerned with drawing a line separating an art world from other parts of a society" (p. 35), whereas Jenkins (1992) views media fandom as constituting "its own distinctive Art World ... founded less upon the consumption of pre-existing texts than on the production of fan texts... These institutions are the infrastructure for a self-sufficient fan culture" (p. 47). In fact, Becker (2008) notes that art worlds, as he uses the term, "typically have intimate and extensive relations with the worlds from which they try to distinguish themselves" (p. 36). They may self-represent as self-sufficient, but this is not at all the sociological reality, as Becker (2008) points out. And reading this against Jenkins' appropriation of art world, it is possible that Textual Poachers adopts fan community as fandom's self-representation to such an extent that it shifts, theoretically, into depicting such community as a sociological and cultural reality, contra Becker's cautionary note. 
And yet, Jenkins' use of art worlds remains subtler and more multivalent than this, because he also concedes that in "one sense, fandom constitutes one component of the mass media "art world", something like the 'serious audience' which Becker locates around the symphony, the ballet, or the art gallery" (Jenkins, 1992, p. 46). This is closer to Becker's usage of the term, insofar as it doesn't seek to separate out fandom from official media producers, "money people," or "support personnel." But Jenkins (1992) offers this application of Becker's ideas first, before then turning to his more familiar assertion of fandom's differentiation and distinction. Indeed, this is an argument that has never quite gone away; Jenkins offers a restatement of this self-sufficiency notion, for example, in a recent discussion with David Gauntlett (2015, pp. 49-51). We might also suggest that the two quite different applications of Becker that Henry Jenkins countenanced back in 1992 are not that far away from where the field of fan studies finds itself in, say, Linden and Linden's Fans and Fan Cultures in 2017, i.e., with one version of fandom that is a component of the media industry, and one version that continues to imagine itself as a self-sufficient fan culture.

Although Becker's approach has not really been developed in fan studies to date, it is worth noting that it has previously provided a pathway out of some of the aporias and difficulties of subcultural theory. In Networks of Sound, Style and Subversion, Nick Crossley (2015) theorizes the "music worlds" of punk and post-punk, focusing on the cities of Manchester, Sheffield, Liverpool, and London. Crossley (2015) observes that the terms subculture and world have actually been used interchangeably by the Chicago School and others, but he ultimately identifies problems with subculture as a concept, including the issue that it struggles to make sense of any "heterogeneous ensemble" (Crossley, 2015, p. 27) of styles or tastes. Set against this weakness, Crossley's (2015) relational sociology examines UK clusters of post-punk activity which have possessed strongly networked ties of competition and co-operation-usually mobilized within specific cities-but which have also shared mediated and weaker ties with networks in other national cities. At the same time, Crossley (2015) follows Becker by not excluding music artists and support personnel from his mapping. The outcome is "clusters... [that] do not remain completely closed off from 
one another [and] the emergence of hubs" (Crossley, 2015, p. 233), making the national "music world" of post-punk not simply a subculturally differentiated domain, or a coherent scene, but instead a network of networks. Indeed, Crossley (2015) argues that networks may be more enduring than the tastes and stylistic conventions that they are linked to at any given moment-hence Manchester's post-punk activity gave way to dance music in the 1980s (p. 246). Theorizing post-punk and dance as different subcultures would miss these networked continuities, as would theorizing many cult TV fandoms as entirely different fan cultures when they are likely to share at least some common fan networks both offline and online.

\section{Conclusion: World in Motion}

In this article I've suggested that we need to take seriously the way in which fan studies has begun to split analyses of fandom between "traditional" and "brand" or "industry-driven" fans (Linden \& Linden, 2017, p. 37; Busse \& Gray, 2014, p. 431), as well as paying close attention to related debates surrounding the place of "first-wave" fan studies and its "Fandom is Beautiful” approach (Coppa, 2014; Sandvoss et al., 2017). These developments-along with work in subcultural theory (Kahn-Harris, 2007; Hannerz, 2015) _ all pose the question as to what place fan community/culture should have within contemporary fan studies. In response, I've argued that continuing to prioritize fan culture (especially by treating this explicitly or implicitly as "true" fandom) fails to consider how fandom imagines and idealizes its community, as well as failing to address the diverse and individualized ways in which fandom can now be performed. To this extent, I am in agreement with the editors of Fandom (Sandvoss et al., 2017). However, although it may be reasonable to assert that "if 'everyone' is a fan, then we must move beyond subcultures" (Linden \& Linden, 2017, p. 43) and concepts of fan difference, it hardly follows from this "participatory condition" (Barney et al., 2016) that fan studies is somehow redundant, nor indeed that a "third wave" can merely broaden out its cataloguing and theorizing practices (Sandvoss et al., 2017, pp. 10-11).

Instead, I have proposed that we draw on "world" theories (Becker, 2008; Connor, 2010) to re-theorize fandom not as community versus in- 
dividualization, nor as an empirical scattering of fan voices and experiences to be academically taxonomized, but rather as a set of pathways or branches which can close down what it means to be a fan for any given person. There are a series of possible ways of doing fandom, or rather ways in which fandom will have been done (Connor, 2010, p. 42), that go to make up a network of networks. Some fan practices remain separated from others, and some might act as nodes bringing diverse versions of fandom together temporarily (corporatized conventions), whilst still others could limit whether one is viewed as a "true" fan by groups on specific platforms, or in particular interpretive communities. Rather than mapping the fan world, the point here is to recognize its fuzzy boundaries and openness, so that theorizing fandom can mean more than merely empirically studying self-declared fans (instead including "support personnel" along with those whose fandom may be disputed or unclaimed), as well as not erecting an a priori or misrecognized line separating the fan world "from other parts of a society" (Becker, 2008, p. 35). Third-wave fan studies have, to date, lacked any strong sense of a fan world. But by shifting our lenses from well-established, commonsensical views of fan culture (as subculturally differentiated and communally constructed) we might begin to perceive fandom in a series of new ways that can go beyond debates over, and performances of, fan authenticity, and which can address where and how acafans or scholar-fans are themselves constituted in the fan world, perhaps having access to certain pathways and practices of fandom. Moving from fan culture to fan world means considering how contemporary fandom is "reflexively mobilized" through "an essentially counterfactual character" (Giddens, 1991, p. 28). Being socialized into a fan community means being policed in relation to communal norms. Participating in one platform-based articulation of fandom (e.g., Tumblr) means having less time and energy to devote to establishing a fan presence elsewhere online. And choosing not to participate in a specific fandom but to experience one's emotional attachment to a text in more private ways might render this "inauthentic" to those for whom "true" fandom means being part of a historically-rooted group. All are possibilities that become (counter)factual as fans follow certain branches but not others, whilst the overall fan world represents the "open necessity" of having to choose a path within our participatory condition. 


\section{References}

Abercrombie, N., \& Longhurst, B. (1998). Audiences. London: Sage.

Amesley, C. (1989). How to watch Star Trek. Cultural Studies, 3(3), 323-339.

Athique, A. (2016). Transnational audiences: Media reception on a global scale. Cambridge: Polity Press.

Barney, D., Coleman, G., Ross, C., Sterne, J., \& Tembeck, T. (2016). The participatory condition: An introduction. In D. Barney, G. Coleman, C. Ross, J. Sterne \& T. Tembeck (Eds.), The participatory condition in the digital age (pp. vii-xxxix). Minneapolis, MN: University of Minnesota Press.

Becker, H. S. (2008). Art worlds: Updated and revised $25^{\text {th }}$ anniversary edition. Berkeley, CA: University of California Press.

Boni, M. (2017). World-building: Transmedia, fans, industries. Amsterdam: Amsterdam University Press.

Bourdieu, P. (1993). The field of cultural production. Cambridge: Polity.

Busse, K., \& Gray, J. (2014). Fan cultures and fan communities. In V. Nightingale (Ed.), The handbook of media audiences (pp. 425-443). Oxford: Wiley-Blackwell.

Carter, O. (forthcoming). Making European cult cinema. Amsterdam: Amsterdam University Press.

Cherry, B. (2016). Cult media, fandom and textiles: Handicrafting as fan art. London and New York, NY: Bloomsbury Academic.

Connor, S. (2010). I believe that the world. In V. Nünning, A. Nünning, \& B. Neumann (Eds.), Cultural ways of worldmaking: Media and narratives (pp.27-46). Berlin and New York, NY: de Gruyter. 
Coppa, F. (2014). Fuck yeah, fandom is beautiful. Journal of Fandom Studies, 2(1), 73-82.

Couldry, N., \& Hepp, A. (2017). The mediated construction of reality. Cambridge: Polity Press.

Crossley, N. (2015). Networks of sound, style and subversion: The punk and post-punk worlds of Manchester, London, Liverpool and Sheffield, 1975-80. Manchester: Manchester University Press.

De Kosnik, A. (2016). Rogue archives: Digital cultural memory and media fandom. Cambridge, MA and London: MIT Press.

Fathallah, J. M. (2017). Fanfiction and the author: How fanfic changes popular cultural texts. Amsterdam: Amsterdam University Press.

Freeman, M. (2017). Historicising transmedia storytelling: Early twentieth century transmedia story worlds. New York, NY and London: Routledge.

Gauntlett, D. (2015). Making media studies: The creativity turn in media and communications studies. New York, NY: Peter Lang.

Giddens, A. (1991). Modernity and self-Identity: Self and society in the late modern age. Cambridge: Polity Press.

Goodman, N. (1978). Ways of worldmaking. Indianapolis, IN: Hackett Publishing.

Hannerz, E. (2015). Performing punk. Basingstoke and New York, NY: Palgrave Macmillan.

Hassler-Forest, D. (2016). Science fiction, fantasy and politics: Transmedia world-building beyond capitalism. London: Rowman and Littlefield International. 
Hellekson, K. (2009). A fannish field of value: Online fan gift culture. Cinema Journal, 48(4), 113-118.

Hellekson, K. (2015). Making use of: The gift, commerce, and fans. Cinema Journal, 54(3), 125-131.

Hill, R. L. (2016). Gender, metal and the media: Women fans and the gendered experience of music. Basingstoke and New York, NY: Palgrave Macmillan.

Hills, M. (2002). Fan cultures. London and New York, NY: Routledge.

Hills, M. (2017a). Transnational cult and/as neoliberalism: The liminal economies of anime fansubbers. Transnational Cinemas, 8(1), 80-94.

Hills, M. (2017b). The enchantment of visiting imaginary worlds and "being there": Brand fandom and the tertiary world of media tourism. In M.J.P.Wolf(Ed.), Revisiting imaginary worlds: A subcreation studies anthology (pp. 244-263). New York, NY and London: Routledge.

Hitchcock Morimoto, L., \& Chin, B. (2017). Reimagining the imagined community: Online media fandoms in the age of global convergence. In J. Gray, C. Sandvoss, \& C. L. Harrington (Eds.), Fandom: Identities and communities in a mediated world - Second edition (pp. 174-188). New York, NY and London: New York University Press.

Jackson, P., Lowe, M., Miller, D., \& Mort, F. (Eds.). (2000). Commercial cultures: Economies, practices, spaces. Oxford and New York, NY: Berg.

Janissary Collective, The. (2013). Participatory culture and media life: Approaching freedom. In A. Delwiche \& J.Jacobs Henderson (Eds.), The participatory cultures handbook (pp. 257-265). New York, NY: Routledge.

Jenkins, H. (1992). Textual poachers. New York, NY and London: Routledge. 
Jenkins, H. (2006). Convergence culture. New York, NY and London: New York University Press.

Kahn-Harris, K. (2007). Extreme metal: Music and culture on the edge. Oxford and New York, NY: Berg.

Larsen, K., \& Zubernis, L. (Eds.). (2012). Fan culture: Theory/practice. Newcastle upon Tyne: Cambridge Scholars Publishing.

Linden, H., \& Linden, S. (2017). Fans and fan cultures. Basingstoke and New York, NY: Palgrave Macmillan.

Lindlof, T.R. (2015). The interpretive community redux: The once and future saga of a media studies concept. In R.A. Lind (Ed.), Produsing theory in a digital world 2.0 (pp. 19-39). New York, NY: Peter Lang.

Lothian, A. (2013). Archival anarchies: Online fandom, subcultural conservation, and the transformative work of digital ephemera. International Journal of Cultural Studies, 16(6), 541-556.

Nünning, A., \& Nünning, V. (2010). Ways of worldmaking as a model for the study of culture: Theoretical frameworks, epistemological underpinnings, new horizons. In V. Nünning, A. Nünning, \& B. Neumann (Eds.), Cultural ways of worldmaking: Media and narratives (pp. 1-26). Berlin and New York, NY: de Gruyter.

Pope, S. (2017). The feminization of sports fandom: A sociological study. London and New York, NY: Routledge.

Ryan, M.-L. (2017). Why worlds now? In M. J.P. Wolf(Ed.), Revisiting imaginary worlds: A subcreation studies anthology (pp.3-13). New York, $\mathrm{NY}$ and London: Routledge.

Saler, M. (2012). As if: Modern enchantment and the literary prehistory of virtual reality. Oxford: Oxford University Press. 
Sandvoss, C., Gray, J., \& Harrington, C. L. (2017). Introduction: Why still study fans? In J. Gray, C. Sandvoss, \& C. L. Harrington (Eds.), Fandom: Identities and communities in a mediated world - Second edition (pp. 1-26). New York, NY and London: New York University Press.

Stein, L. (2015). Millennial fandom. Iowa City, IA: University of Iowa Press.

Thon, J.-N. (2016). Transmedial narratology and contemporary media culture. Lincoln, NE and London: University of Nebraska Press.

Thornton, S. (1995). Club cultures: Music, media and subcultural capital. Cambridge: Polity.

Van de Goor, S. (2015). "You must be new here": Reinforcing the good fan. Participations, 12(2), 275-295.

Woodward, I. (2007). Understanding material culture. London: Sage.

Wolf, M. J. P. (2012). Building imaginary worlds: The theory and history of subcreation. New York, NY and London: Routledge. 